

Istanbul Finance Congress (IFC), November 2-3, 2017, Istanbul, Turkey

\title{
RELATIONSHIP BETWEEN PROFITABILITY RATIOS AND STOCK PRICES: AN EMPIRICAL ANALYSIS ON BIST-100
}

\author{
DOI: 10.17261/Pressacademia.2017.737 \\ PAP-IFC- V.6-2017(1)-p.1-10
}

\author{
Ali Bayrakdaroglu ${ }^{1}$, Cagatay Mirgen ${ }^{2}$, Ezgi Kuyu ${ }^{3}$ \\ ${ }^{1}$ Mugla Sitki Kocman University, School of Business, Kotekli, Mugla, Turkey. abayrakdaroglu@mu.edu.tr \\ ${ }^{2}$ Mugla Sitki Kocman University, Instute of Social Sciences, Kotekli, Mugla, Turkey. cagataymirgen@ hotmail.com \\ ${ }^{3}$ Mugla Sitki Kocman University, Fethiye School of Business, Fethiye, Mugla, Turkey. ezgikuyu@mu.edu.tr
}

\section{To cite this document}

Bayrakdaroglu, A., Mirgen, C., Kuyu, E., (2017). Relationship between profitability ratios and stock prices: an empirical analysis on BIST-100. PressAcademia Procedia (PAP), V.6.,p.1-10.

Permanant link to this document: http://doi.org/10.17261/Pressacademia.2017.737

Copyright: Published by PressAcademia and limited licenced re-use rights only.

\begin{abstract}
Purpose- Investors benefit from a large number of information resources in order to maximize their earnings from financial instruments they have invested. One of the resources that investors benefit from is financial ratio information which they obtain by analyzing firms' financial statements. Accordingly, the aim of this study is to determine if there is a relationship between stock prices and profitability ratios which take place in financial ratios and also to analyze if profitability ratios can be directive indicator while investing in stocks with the aim of maximizing earnings.

Methodology- In this research, panel data regression analysis was applied between lagged stock prices of firms in ISE100 and their profitability ratios including gross profit margin, operating profit margin, net profit margin, return on asset and return on equity. Once we had decided that fixed effects model is convenient for our research, the model was estimated by Driscoll-Kraay Estimator which produce robust standard errors.

Findings- According to result of our analysis, it was determined that there is a positive linear relationship between firms' net profit margin and their stock prices.

Conclusion- It was concluded that while making investment decisions, taking net profit margin into consideration can contribute to investors' earnings.
\end{abstract}

Keywords: Stock Prices, Panel Data Regression, Profitability Ratios, ISE100, Driscoll and Kraay Estimator JEL Codes: C33, G10, M41

\section{INTRODUCTION}

Stock certificates take important place in investment instruments (Arkan, 2016, p. 20). In 2016, the total trading volume of İstanbul Stock Exchange markets increased by $9.4 \%$ compared to year 2015 and reached 13,02 trillion TL. The stock market constitutes 7.8\% of the total trading volume and the stock market trading volume was 1.014 billion TL. (Bist, 2016 Annual Report: p.22). Additionally, the highest return of all investment instruments in 2017 was realized in ISE100 index (http://www.tuik.gov.tr). In general, investors aim to get dividend yield generating from firms' profitability and as well as to get capital gain from the increasing value of the stock by investing in stocks. In order to maximize earnings, investors can benefit from financial ratios. Financial ratios should also be included into decision-making process on behalf of pursuing right investment strategy. One of the financial ratio items based on financial statements is the profitability ratios of the companies. In other words, profitability ratios can be guiding factors for the investors in the preference of stocks they will invest in (Eka, Purnamasari, Purnamasari and Gautama, 2016, p. 157) (Ferrer and Tang, 2016, p. 104) (Mokhtar, Shuib and Mohamad, 2014, p. 348).

Because of the fact that stock certificates are very risky investment instruments, it is necessary to know the factors affecting stock prices (Ayaydın and Dağlı, 2012: p.46). Predicting future stock prices is significant from the point of investment's expected return. Reliability of future stock price predictions requires to specify factors affecting stock prices in accurate and meaningful way (Güngör and Yerdelen Kaygın, 2015, p.151). It is known that there are macro-economic factors or some other factors such as dividend payments which affect stock prices in the capital markets (Demir, 2001, p. 109-112) (Çoşkun, Kasım and Muhammed, 2016, p. 61) (Ullah, Sagip and Usman, 2016, p. 2). Firm-specific factors which have an important place in these, need to be considered within the scope of 
fundamental analysis by the investors who want to invest in stock certificates (Kaya and Öztürk, 2015, p. 38). Profitability ratios, one of the firm-specific factors, are considered as an important factor that investors take into account when deciding on stock investment (Sharif, Purohit and Pillai, 2015, p. 207-209) (Aktaş and Ünal ,2015, p. 2). According to this, the aim of this study is to analyze the relationship between profitability ratios and stock prices in terms of obtaining expected return of investor's stock invesment and also to examine whether profitability ratios can be directive indicator in investment decisions.

The main difference of this study from other studies is that capital gain was taken into consideration as a return of stock investment. Differences in companies' dividend payment dates, inability to pay dividend payments in case firms does not make a profit and increase in stock prices although the company faces loss engendered an emphasis on capital gains. In this regard, ISE-100 companies which are more frequently traded got involved in our study and analysis was carried out with 87 companies. In the following sections of the study, firstly literature was reviewed, national and international studies were examined extensively. Then, in addition to research hypothesis and model, data set and method were mentioned. Finally, results were evaluated after research findings and discussions had presented in details. In this context, it is expected that results of the study can make a contribution to ISE investors and the literature.

\section{LITERATURE REVIEW}

The relationship between the financial ratios of the companies and the performance of stock certificates has been a subject of a large number of studies until this time (Narayan and Reddy, 2016, p. 195). When the literature relating to the subject was reviewed, studies based on profitability ratios can be grouped into two groups as stock price and stock return studies. There are a wide range of studies that examine the relationship between stock returns and firms' profitability ratios, however, the studies of the relationship between share price and profitability rates are in more limited numbers. These studies comprise of different research areas in terms of methods and profitability ratios used, sectors, number of firms and periods. For instance, Cengiz and Püskül (2016) tried to identify profitability ratios which are related with stock returns; Parlakkaya and Kahraman (2017) investigated the effects of accounting information on explanation of stock prices. While using ISE-100 index companies as a base, researchers Karaca and Başcı (2011) chose firms that are persistent in ISE-30. On the other hand, Aydemir, Ögel and Demirtaş (2012), also Kaya and Öztürk (2015) split companies into sectors and then analyzed them. In the context of these studies, selected indexes and sectors differ in terms of the number of companies dealt with and the periods in which the study's data set was formed. Generally, studies have similar empirical findings. Some of these studies are given below

Parlakkaya and Kahraman (2017), did research with the data set of 77 firms which place in ISE-100 index between the years 2012-2015 so as to determine the degree of explanation of stock prices with firms' accounting information. In the research, earnings per share and book value per share was taken into consideration as independent variables and share price was considered as dependent variable. At the end of the panel data regression analysis, they indicated that stock price movements are directly proportional to profitability ratios. In other words, accounting information obtained from the company's balance sheet and income statements have a role in explaining stock prices of the firm.

Cengiz and Püskül (2016) revealed the relationship between profitability and stock returns by identifying that increase in profitability of equity and gross sales margin lead to increase in stock returns whereas increase in operating profit margin result in decrease in stock prices. Arkan (2016) examined the significance of financial ratios in order to predict stock price trends in emerging markets. In Kuwaiti financial market between the years 2005-2014, prediction power of 12 financial ratios was analyzed based upon data set of 15 firms' which take place in three different sectors. As a result, it was founded that the most effective ratios are ROA, ROE and net profit ratio in industry sector while these are ROA, ROE, price-to-earnings ratio and earnings per share in service and investment sector. Sevim (2016) studied the effect of financial ratios including the sales, asset and equity profitability ratios on stock returns over 32 manufacturing entities. Finally, this study revealed that there is no statistically significant relationship between these profitability ratios and stock returns.

Sharif, Purohit and Pillai (2015) analyzed panel data set of 41 firms traded in Bahrain Stock Exchange during the period 2006-2010. In this study which firm size was used as a control variable, effects of entity-specific variables such as return on equity, book value per share, earnings per share, dividend per share, dividend yield, price earnings, debt to assets on market price of stocks was analyzed. Results of the study indicates that, return on equity, book value per share, dividend per share, dividend yield, price earnings ratio and firm size variables are important determinants of stock prices in Bahrain Stock Exchange. In Aktaş and Ünal (2015)'s research that is related with insurance companies, researchers tried to confirm whether there is a relationship between stock prices and three groups of efficiency ratios including cost, revenue and profit. Sampling period comprises of 2005Q1-2012Q4. As a consequence, meaningful relationships between efficiency ratios and stock prices were ascertained and also profitability ratios are more powerful than other ratios. Kaya and Öztürk (2015) examined the relationship between profits and stock prices of BIST Food, Beverage and Tobacco Sector within the period of 2000-2013. According to result of the analysis, profits and stock prices are cointegrated and it is revealed that there is a one-way causality from return on assets and net profit margin to stock prices; in addition, there is a bidirectional causality between net operating profitability and stock prices.

Kohansal, Dadrasmoghaddam, Karmozdi and Mohseni (2013) carried out a study which investigates the relationship between food companies traded in Iran Stock Exchange and their stock prices with the data set from 1992 to 2010. As independent variables they used liquidity ratio (current ratio), activity ratio (asset turnover), profitability ratio (return on assets and return on equity), financial leverage ratio (debt ratio); and also, as dependent variable they used stock prices. Consequently, stock prices react positively and meaningfully against current ratio, ROA and ROE shocks. Although they react positively and meaningfully against financial leverage ratios in the beginning, it fluctuates afterwards.

Aydemir, Ögel and Demirtaş (2012) tried to determine financial ratios that are effective in specifying stock prices by using the data set of 73 companies in the manufacturing sector from the year 1990 to 2009. At the end of the study, it is determined that financial ratios' effect on determining stock prices is low, however, net profit margin, return on equity and operating profit margin affects stock returns positively and statistically meaningful. 
In the Karaca and Başçı (2011)'s studies, financial ratios related with stock returns was examined. The data set includes 14 companies traded in ISE-30 between the years 2001 and 2009. At the end of the study, they confirmed that there is a meaningful relationship between stock returns and profitability ratios that are net profit margin and operating profit margin. Aktaş (2008) found that the stock certificates traded in the ISE during 2003-2006 are positively correlated with the gross profit / sales and net profit / sales ratios. Demir (2001), in the study examining firm level factors that determine financial sector stock prices, found that market value/book value is the most effective entity-specific determinant that determine financial sector stock prices. After this, earnings per share, price/earnings ratio and return on asset ranked. On the other hand, net profit growth rate, transaction rate and dividend payout ratio affects stock prices less than previous ratios. After Chu and Lim (1998) had evaluated the cost and profit efficiency of six banks in Singapore between 1992-1996, they indicated that changes in stock prices reflect changes in profit rather than changes in cost efficiencies.

\section{RESEARCH HYPOTHESIS AND THE MODEL}

Fundamental motivation of this research is that according to existence of relationship between profitability ratios announced by stock exchange companies traded in financial markets and the stock prices, these ratios can be a directive factor for investors' investment decisions. In this context, the basic hypothesis to be tested is as follows;

$\mathrm{H}_{0}$ : There is no relationship between profitability rates and stock prices

$\mathrm{H}_{1}$ : There is a relationship between profitability rates and share prices

In addition to the basic hypothesis, the relationship between each profit rate and the stock price was also tested. Considering the hypothesis, the model that was created in the research is as shown in Figure-1 below.

Figure-1: Research Model

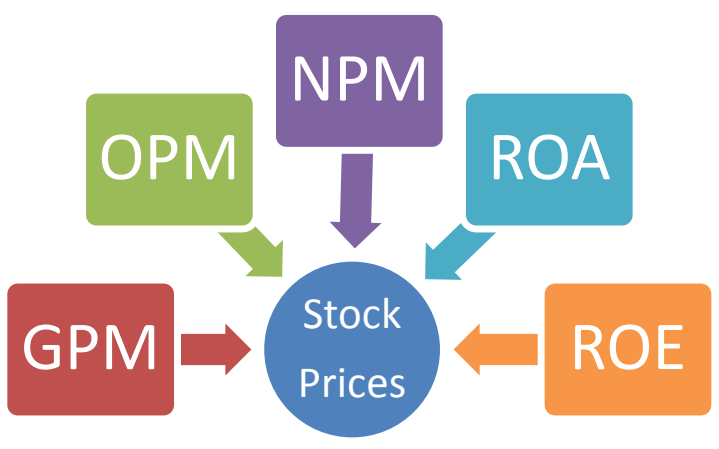

According to this, in the study, panel regression analysis was implemented between the lagged values of the stock price and the profitability ratios obtained from the balance sheet of the firms. Here in the analysis, NPM, OPM, GPM, ROA and ROE profitability ratios which are thought to affect stock prices were used. In other words, the question of which ratio investors look at while making investment decision was tried to be answered.

\section{DATA SET AND THE METHODOLOGY}

The data set of variables included in the research obtained from Finnet Analysis Expert ${ }^{1}$ software program. Data values that belong to variables of 87 companies traded in ISE-100 were taken in consideration in dollar ${ }^{2}$ basis in order to purify from the effects such as seasonality and inflation.

While forming data set, quarterly profit figures during the period of 2012:12-2017:03 was used. Aktaş and Ünal, formed their study's data set with the quarterly data, as well. While creating stock price data, the lagged values were taken into account as 1 month, 2 months and 3 months after each quarter period ${ }^{3} .1566$ observations were obtained by using panel data set. In order to increase significance level, firm size which was considered as company's market value was used as a control variable (Sharif, Purohit, and Pillai, 2015, p.210). While the logarithmic transformation of the firm size variable is used in the analyzes, the proportional values in percentage were used for all other variables. The data and resources analyzed are given in Table 1.

\footnotetext{
${ }^{1}$ Finnet Analiz Expert is the licensed financial analysis software program which allows users to prepare reports of detailed data sets relating to Turkish capital market instruments in excel format. http://www.analizexpert.com/Tr

${ }^{2}$ CBRT effective buying rates was taken into consideration as an exchange rate.

${ }^{3}$ For instance, while forming the data set of first quarter, forth month value was considered for the 1 month lagged stock prices; fifth month value was taken for the 2 months lag and sixth month value for the 3 months lagged stock prices.
} 
Table 1: Data Definitions and Sources

\begin{tabular}{|c|c|c|c|}
\hline Variables & Definitions & Abbreviations & Expected \\
\hline \multicolumn{4}{|l|}{ Explanatory Variables } \\
\hline Return on Assets & Net Profit/ Average Total Asset & ROA & $+/-$ \\
\hline Return on Equity & Net Profit for the Period/ Shareholders' Equity & ROE & $+/-$ \\
\hline Gross Profit Margin & Gross Profit / Net Sales & GPM & + \\
\hline Operating Profit Margin & Operating Profit / Net Sales & OPM & + \\
\hline Net Profit Margin & Net Profit /Net Sales & NPM & + \\
\hline \multicolumn{4}{|l|}{ Dependent Variables } \\
\hline 1 Month Lagged Price & Average monthly price in ISE after 1 month & P1 & \\
\hline 2 Months Lagged Price & Average monthly price in ISE after 2 months & $\mathrm{P} 2$ & \\
\hline 3 Months Lagged Price & Average monthly price in ISE after 3 months & P3 & \\
\hline \multicolumn{4}{|l|}{ Control Variable } \\
\hline Firm Size & $\begin{array}{l}\text { As a market value, it was calculated multiplying stock price by } \\
\text { number of stocks in circulation }\end{array}$ & Log FS & + \\
\hline
\end{tabular}

In order to increase predictive power of the analysis, extreme values in series were excluded. Because of using balanced panel data set, companies which have incorrect or extreme values were excluded completely. Therefore, 87 firms in ISE-100 were suitable for the analysis. Descriptive statistics of the series of variables used in the analysis are shown in Table 2.

Table 2: Descriptive Statistics of Variables

\begin{tabular}{lccccccccc}
\hline & ROA & ROE & GPM & FKM & NPM & P1 & P2 & P3 & FS** \\
\hline Mean & 3.07 & 4.93 & 23.25 & 7.71 & 5.57 & 4.73 & 4.73 & 4.62 & 8,73 \\
Median & 2.41 & 5.59 & 19.89 & 7.14 & 5.31 & 2.23 & 2.23 & 2.17 & 8,66 \\
Maximum & 38.73 & 103.36 & 152.94 & 78.83 & 217.28 & 39.08 & 37.49 & 34.98 & 10,19 \\
Minimum & -36.61 & -64.93 & -20.18 & -67.66 & -97.62 & 0.07 & 0.07 & 0.07 & 6,79 \\
Std. Deviation & 5.80 & 25.39 & 18.06 & 10.36 & 16.45 & 6.51 & 6.49 & 6.33 & 0,63 \\
Skewness $^{4}$ & -0.08 & -12.49 & 2.78 & 0.75 & 2.84 & 2.41 & 2.39 & 2.37 & 0,14 \\
Kurtosis $^{5}$ & 9.73 & 28.48 & 13.84 & 12.06 & 40.15 & 8.74 & 8.65 & 8.43 & 2,74 \\
Jarque-Bera & $2313^{*}$ & $4015^{*}$ & $7571^{*}$ & $4306^{*}$ & $72045^{*}$ & $2868^{*}$ & $2806^{*}$ & $2654^{*}$ & 9,70 \\
N of Observations & 1566 & 1566 & 1566 & 1566 & 1566 & 1566 & 1566 & 1566 & 1566 \\
\hline$*$
\end{tabular}

* It shows \%1 significance level

$* *$ It is shown in logarithmic base

As seen in Table 2, GPM has the highest mean value among other variables used in analysis. Therefore, having the lowest mean value for NPM is normal. When we look at the monthly basis lagged stock prices, it can be seen that mean values are around 4 . Statistical values belong to price variable is very close to each other. In addition, ROE has the highest volatility whereas ROA has the lowest one. In terms of kurtosis values, it can be said that all variables are steeper than the normal distribution. When the skewness values are examined, it is seen that the variables except for ROA and ROE are inclined to the right. Moreover, Jarque-Bera values indicate that the series belong to variables are not normally distributed.

In the scope of research methodology, first of all, dependency between cross sections (firms) was examined by Pesaran (2004) $\mathrm{CD}_{\mathrm{LM}}$ test. The main basis of this test is $\mathrm{N}>\mathrm{T}$ principle. In the study, there are 18 periods/years ( $\mathrm{T}$ ) which cover 2012:12-2017:03 and 87 firms ( $\mathrm{N}$ ), therefore Pesaran (2004) $C_{L} D_{L M}$ test's conditions were provided (Wu, Liu and Hsueh, 2016, p. 114) (Le, Kim and Lee, 2016, p. 1053)(Hepaktan \& Çınar, 2012, p. 48-49). Stationary of series was tested by unit root tests. Variables used in analyzes have to be stationary so that they do not cause spurious relationships in panel data analysis (Şak, 2015, p. 203-204). Due to the fact that cross-sectional dependency exists between variables, they were tested by Pesaran (2007) which is one of the second generation panel unit root tests (Hamit-Haggar, 2012, p. 361). This test uses one of the Augmented Dickey-Fuller regression models which is extended with horizontal cross section analysis. For that reason, it is also called Cross-Sectionally Augmented Dickey-Fuller (CADF) test (Tatoğlu, 2016, p. 223).

Panel regression model was established in order to test which profitability ratios are effective in explaining changes of stock prices. Parlakkaya and Kahraman (2017), Cengiz and Püskül (2016), Sevim (2016), Sharif, Purohit and Pillai (2015), Khan (2011) also examined their studies with the panel data. Estimation method to be used was determined according to the presence of unit and time effects of the series. After that, basic assumptions such as heteroskedasticity (non-constant variance), autocorrelation and cross-section dependency were tested in the generated model. It was decided to use a robust estimator based on whether the model tested provides assumptions for panel data models. The econometric model to be tested according to the basic hypothesis of the research is as follows:

$$
S P=(P R, C V)
$$

Here, as a basic model spesification; SP symbolizes stock price which is dependent variable of the model; PR represents profitability ratios that is explanatory variable and CV stands for control variable. Considering the relationship between dependent and independent variable,

\footnotetext{
${ }^{4}$ The absolute value of the skewness which is greater than 0.5 indicates strong asymmetry in series (Serper, 2000).

${ }^{5}$ The kurtosis is compared with the value 3 when comparing with the normal distribution.
} 
control variable was used in order to increase the explanatory power of the model. The econometric models generated in the context of hypotheses to be tested in the research, derived from the general model, are as follows;

$$
\begin{aligned}
& P_{(d 1) i t}=\alpha+\beta_{1} G P M_{i t}+\beta_{2} O P M_{i t}+\beta_{3} N P M_{i t}+\beta_{4} R O A_{i t}+\beta_{5} R O E_{i t}+\beta_{6} \log F S_{i t}+\varepsilon_{i t} \ldots t=1 \text { ve } i=1 \ldots N \ldots . \text { Model-1(M1) } \\
& P_{(d 2) i t}=\alpha+\beta_{1} G P M_{i t}+\beta_{2} O P M_{i t}+\beta_{3} N P M_{i t}+\beta_{4} R O A_{i t}+\beta_{5} R O E_{i t}+\beta_{6} \operatorname{LogFS} i t+\varepsilon_{i t} \ldots t=1 \text { ve } i=1 \ldots . . . . . \text { Model-2(M2) } \\
& P_{(d 3) i t}=\alpha+\beta_{1} G P M_{i t}+\beta_{2} O P M_{i t}+\beta_{3} N P M_{i t}+\beta_{4} R O A_{i t}+\beta_{5} R O E_{i t}+\beta_{6} \log F S_{i t}+\varepsilon_{i t} \ldots t=1 \text { vei=1....N....Model-3(M3) }
\end{aligned}
$$

In the analysis of relationship between profitability ratios and stock prices, three different models were formed by using 1,2 and 3 months lagged $(\mathrm{d} 1, \mathrm{~d} 2, \mathrm{~d} 3)$ stock prices as dependent variables. The main reason for using lagged values is that investors do not immediately response to profitability ratios declared by the companies. Furthermore, quarterly GPM, OPM, ROA, ROE and NPM values were used as independent variables. All analyzes were implemented by E-Views 8 and Stata 14.1 statistical software package programs.

\section{RESEARCH FINDINGS AND DISCUSSION}

First generation unit root tests base on the cross-sectional dependency assumption. Therefore, it assumes that there is no correlation between units. However, cross-sectional dependency requires to be tested because of the probability of having unit or time effects in panel data models. This situation is statistically significant due to the fact that the distributions and $t$ statistics on which traditional tests are based, are valid under cross-sectional independency (ilgün, 2016, p. 80). From a financial point of view, when an economic development is likely to affect businesses as cross-sectional units and thus affecting businesses operating in the same ecosystem (for example being traded in the same stock exchange), second generation panel unit root tests based on the assumption of cross-sectional dependency require to be used (Hurlin and Mignon, 2007, p. 3).

Table 3: Cross-Sectional Dependence Test Results

\begin{tabular}{lcc}
\hline Variables & \multicolumn{2}{c}{ Pesaran $(2004) C D_{L M}$} \\
\hline & CD test & P value \\
\hline GPM & 10,67 & 0,000 \\
OPM & 7,78 & 0,000 \\
NPM & 3,31 & 0,001 \\
ROA & 40,43 & 0,000 \\
ROE & 36,62 & 0,000 \\
P1 & 35,08 & 0,000 \\
P2 & 35,20 & 0,000 \\
P3 & 35,52 & 0,000 \\
fs & 36,89 & 0,000 \\
\hline
\end{tabular}

Table 3 demonstrates cross-sectional dependence test results. The null hypothesis of cross-sectional independence was rejected. According to this, it was decided that cross-sectional dependency exists in series because of being $p$-value less than 0,05 . In this situation, crosssectional dependency was observed in profitability ratios of 87 firms trading in stock exchange. With this result, panel unit root tests which take cross-sectional dependency into consideration were used to make effective prediction. In this respect, Pesaran (2007) CADF unit root

\begin{tabular}{|c|c|c|c|c|c|c|c|}
\hline \multirow[t]{2}{*}{ Variables } & \multicolumn{3}{|c|}{ Pesaran 2007 table critical values*** } & \multirow[t]{2}{*}{ t-bar } & \multirow[t]{2}{*}{ p value } & \multirow[t]{2}{*}{ t-bar } & \multirow[t]{2}{*}{ p value } \\
\hline & cv10(\%10) & cv5 (\%5) & cv1(\%1) & & & & \\
\hline GPM & & & & $-2,090$ & 0,936 & $-3,118 \mid(2)$ & 0,000 \\
\hline OPM & & & & $-1,817$ & 1,000 & $-3,124 \mid(2)$ & 0,000 \\
\hline NPM & & & & $-2,329$ & 0,348 & $-2,803 I(1)$ & 0,000 \\
\hline ROA & & & & $-2,221$ & 0,682 & $-2,531 I(1)$ & 0,022 \\
\hline ROE & $-2,530$ & $-2,590$ & $-2,720$ & $-2,682$ & 0,001 & - & - \\
\hline P1 & & & & $-1,923$ & 0,998 & $-2,851 \mid(1)$ & 0,000 \\
\hline P2 & & & & $-1,791$ & 1,000 & $-2,582 I(1)$ & 0,008 \\
\hline P3 & & & & $-1,554$ & 1,000 & $-2,689 \mid(1)$ & 0,000 \\
\hline fs & & & & $-1,815$ & 1,000 & -2,761 (1) & 0,000 \\
\hline
\end{tabular}
test results of variables are given in Table 4.

Table 4: CADF Unit Root Test Results

* The model with constant and trend was used.

** Lag lengths are determined according to the Schwarz information criterion.

$* * *$ The critical values of CADF statistic are considered as $-2,530(10 \%),-2,590(5 \%)$ and $-2,720(1 \%)$ in the constant and trend model (Pesaran 2007, Table 1-b, p.275),

Considering the results in Table-4, when t-bar statistic values of all other variables except for ROE are compared with both $1 \%, 5 \%$ and $10 \%$ critical table values and the related $p$ values are more than 0,005; it can be seen that the null hypothesis can not be rejected. Accordingly, it can be concluded that except for ROE, all the variables used in the analysis are not stationary at level and contains unit root I(0). When these results are taken into account, while providing stationarity of GPM and OPM by taking second degree differences [respectively, $3,118 \mathrm{I}(2)$ and $-3,124 \mathrm{I}(2)$ ]; stationarity of other variables' series was provided by taking first degree differences [respectively, $-2,803 \mathrm{I}(1)$, - 
2,531 I(1), $-2,851 \mathrm{I}(1),-2,582 \mathrm{I}(1),-2,689 \mathrm{I}(1)$ and $-2,761 \mathrm{I}(1)]$. Consequently, it has been found that ROA is statistically significant at $5 \%$ significance level and the other variables in series are statistically significant at $10 \%$ significance level.

Primarily, it is important that estimation method to be used in the panel regression model requires to be specified in order to test which profitability ratios are effective in explaining changes of stock prices. In general, pooled regression, fixed effect regression and random effect regression models which reveal data aggregation are used. These models perform with the assumption that cross-sectional dependecy, autocorrelation or non-constant variance does not exist (Mert, 2016, p. 135). If one or more of these assumptions are found, the loss of efficiency in the predicted variables and the incorrect predictions of standard errors will be reached. For this reason, after the model is estimated, it is tested whether these assumptions are valid (Ün, 2015, p.71). In the absence of unit and/or time effects in the error term, in other words, if the observations are homogeneous, the pooled regression model is preferred, however, if the model has unit and/or time effects, it is more convenient to use the fixed or random effects model (Tatoğlu, 2016, p. 40-45). In this point, the BreuschPagan (1980) Lagrange Multiplier (LM) test was used to make a choice between the pooled and random effect panel data models in the panel regression model. The Breusch-Pagan LM (1980) test examines the existence of individual heterogeneity. In other words, it tests whether the estimated pooled least squares model is suitable, against to the random effects model. This test is based on the hypothesis that the variance of random unit effects is zero (Yerdelen Tatoğlu, 2016: 178). Table-5 demonstrates Breusch-Pagan LM (1980) test results.

Table 5: Breusch Pagan LM (1980) Test Results

\begin{tabular}{|l|c|c|c|}
\hline Breusch Pagan $_{\text {LM }}(1980)$ & Model-1 & Model-2 & Model-3 \\
\hline Test statistics & 8478,12 & 8467,95 & 8548,74 \\
\hline p value & 0,000 & 0,000 & 0,000 \\
\hline
\end{tabular}

As a result of the LM test, at 1 degree of freedom, the test statistic chi-square value was 8478,12 for Model-1 and $p$-value was 0,000 at $1 \%$ significance level. According to these results, the null hypothesis that the variance of unit effects is equal to zero is rejected and it is determined that the pooled model is not convenient for the analysis ${ }^{6}$. In other words, since it is determined that unit and/or time effects exist in the formed panel data model, it has come to the stage of deciding whether these effects are fixed or random. After this stage, Hausman (1978) test was used to choose between fixed effect and random effect panel data models. Hausman test, examines the basic hypothesis that random effects estimator is valid, by chi-squared distribution with k degrees of freedom (Tatoğlu, 2016, p. 185). Table-6 shows Hausman (1978) test results.

Table 6: Hausman (1978) Test Results

\begin{tabular}{|l|c|c|c|}
\hline Hausman (1978) & Model-1 & Model-2 & Model-3 \\
\hline Test statistics & 30,39 & 19,47 & 11,55 \\
\hline$p$ value & 0,000 & 0,003 & 0,072 \\
\hline
\end{tabular}

As a result of the analysis, for the Model-1 Hausman test statistics is 30,39 and p-value was found 0,000. According to these results, random effect model estimator is biased. Therefore, explanatory variables and unit(time) effects are correlated, so it is determined that fixed effect panel data model is more convenient for analyzes ${ }^{7}$.

Cross-sectional dependency, autocorrelation and non-constant variance problems related to fixed effect model in the panel data model in which relationship between profitability ratios and stock prices was examined, were tested. The model has to meet all these assumptions. With this purpose, non-constant variance problem was tested via Modified Walt test (Greene, 2002, p. 324). This test examines the null hypothesis that the variance of each unit is equal to the panel average. It is tested whether the variance changes according to the units (Ün, 2015, p. 78). Baltagi-Wu (1999) LBI test and Bhargava, Franzini and Narendranathan (1982) Durbin Watson d tests were used concerning the existence of autocorrelation in the model. Both these tests are used in fixed effect model as well as random effect model. In both tests, the null hypothesis is that the autocorrelation coefficient is equal to zero, and the alternative hypothesis is that autocorrelation exists in the first difference (AR1). Finally, Pesaran (2004) $C D_{L M}$ test was used because of having cross-sectional dependency ( $N>T$ ) in the model. The null hypothesis reveals that there is no cross-sectional independence. In this respect, the test results for the validity of the three basic assumptions are given in Table 7 below.

Table 7: Modified Wald, LBI Durbin Watson d, CD ıM Test Results

\begin{tabular}{|c|c|c|c|c|c|c|c|}
\hline \multirow{2}{*}{ Assumption Tested } & \multirow{2}{*}{ Test Used } & \multicolumn{3}{|c|}{ Test Statistics } & \multicolumn{3}{|c|}{ P Value / Critical Value } \\
\hline & & Model-1 & Model-2 & Model-3 & Model-1 & Model-2 & Model-3 \\
\hline Non-constant Variance & Modified Wald & $1.4 \mathrm{e}+05$ & 72373,85 & 60943,88 & 0,000 & 0,000 & 0,000 \\
\hline Autocorrelation & $\begin{array}{c}\text { LBI } \\
\text { Durbin Watson d }\end{array}$ & $\begin{array}{l}0,89401359 \\
0,71545896\end{array}$ & $\begin{array}{c}0,84356187 \\
1,0350796\end{array}$ & $\begin{array}{l}0,82175699 \\
1,0191473\end{array}$ & $<2$ & $<2$ & $<2$ \\
\hline Cross-Sectional Dependence & $\mathrm{CD}_{\mathrm{LM}}$ & 8.384 & 27,856 & 39,621 & 0,000 & 0,000 & 0,000 \\
\hline
\end{tabular}

When Table-7 was examined, according to Modified Wald test results, it is seen that there is a non-constant variance problem within the scope of Model-1 because of being the $p$ value $<0,000$. LBI and Durbin Watson $d$ tests, also indicate that there is autocorrelation in the models due to the fact that values are below 2 . Moreover, $C D$ LM test results reveal that cross-sectional independency was not met in the

\footnotetext{
${ }^{6}$ The similar results were also obtained in Model-2 and Model-3.

${ }^{7}$ The similar results were also obtained in Model-2 and Model-3 (10\% significance level).
} 
model. In conclusion, none of the test assumptions could be provided ${ }^{8}$. In the presence of at least one of heteroskedasticity (non-constant variance), autocorrelation and correlations between units, predictions are inconsistent but effective. Therefore, standard errors should be corrected without making changes in parameter predictions, in other words, robust standard errors should be obtained (Dücan \& Akal, 2017, p. 70). In this situation, estimator to be used in the model has to be robust estimator. Hence, the model was analyzed with the Driscoll and Kraay estimator that generates robust standard errors. The Driscoll and Kraay estimator generates standard error terms based on the averages of the cross-sectional units, irrespectively from N number (Tatoğlu, 2016, p. 278). Therefore, after Driscoll and Kraay test, removed three biases in the model, had implemented, the ultimate model was formed. The model in which the stock price ratios are explained by the profitability ratios, is estimated by Driscoll-Kraay (1998) estimator and the test results are given in Table-8.

Table 8: Driscoll-Kraay Estimator and the Test Results

\begin{tabular}{|c|c|c|c|c|c|c|c|c|c|c|c|c|}
\hline & \multicolumn{4}{|c|}{$\begin{array}{c}\text { Model-1 } \\
\text { Dependent Variable p1 }\end{array}$} & \multicolumn{4}{|c|}{$\begin{array}{c}\text { Model-2 } \\
\text { Dependent Variable p2 }\end{array}$} & \multicolumn{4}{|c|}{$\begin{array}{c}\text { Model-3 } \\
\text { Dependent Variable p3 }\end{array}$} \\
\hline & Coeff & $\begin{array}{l}\text { Std. } \\
\text { Error }\end{array}$ & $\begin{array}{c}\text { t } \\
\text { Value }\end{array}$ & $P>|t|$ & Coeff & $\begin{array}{l}\text { Std. } \\
\text { Error }\end{array}$ & $\begin{array}{c}t \\
\text { Value }\end{array}$ & $P>|t|$ & Coeff & $\begin{array}{l}\text { Std. } \\
\text { Error }\end{array}$ & $\begin{array}{c}t \\
\text { Value }\end{array}$ & $P>|t|$ \\
\hline GPM & 0,0095 & 0,0138 & 0,69 & 0,500 & 0,0112 & 0,0133 & 0,85 & 0,408 & 0,013 & 0,0109 & 0,49 & 0,632 \\
\hline OPM & $\begin{array}{c}- \\
0,0176\end{array}$ & 0,0110 & $-1,60$ & 0,127 & $\begin{array}{c}- \\
0,0140\end{array}$ & 0,0102 & $-1,38$ & 0,187 & $-0,014$ & 0,0088 & $-1,62$ & 0,123 \\
\hline NPM & 0,0140 & 0,0042 & 3,30 & 0,004 & 0,0186 & 0,0054 & 3,40 & 0,003 & 0,0132 & 0,0037 & 3,50 & 0,003 \\
\hline ROA & 0,0170 & 0,0167 & $-1,02$ & 0,324 & 0,0196 & 0,2111 & $-0,93$ & 0,366 & 0,0119 & 0,0244 & 0,49 & 0,632 \\
\hline ROE & 0,0015 & 0,0008 & $-1,76$ & 0,096 & 0,0004 & 0,0009 & $-0,54$ & 0,599 & 0,0018 & 0,0011 & $-1,61$ & 0,126 \\
\hline Fs & 7,6048 & 0,3204 & 23,73 & 0,000 & 6,7755 & 0,5472 & 12,38 & 0,000 & 5,8405 & 0,5787 & 10,09 & 0,000 \\
\hline Constant & 62,453 & 2,6635 & $-23,45$ & 0,000 & $\begin{array}{r}- \\
55,234 \\
\end{array}$ & 4,6107 & $-11,98$ & 0,000 & $\begin{array}{r}- \\
47,196 \\
\end{array}$ & 4,9471 & $-9,54$ & 0,000 \\
\hline $\mathbf{R}^{2}$ & 0,38 & & & & & 0,32 & & & & 0,28 & & \\
\hline $\begin{array}{l}\mathrm{N} \text { of } \\
\text { observations }\end{array}$ & 1224 & & & & & 1224 & & & & 1224 & & \\
\hline $\begin{array}{l}\text { F value } \\
p \text { value }\end{array}$ & $\begin{array}{l}339,87 \\
(0,000)\end{array}$ & & & & & $\begin{array}{l}216,20 \\
(0,000) \\
\end{array}$ & & & & $\begin{array}{c}80,31 \\
(0,000)\end{array}$ & & \\
\hline
\end{tabular}

According to analysis results, all three models are statistically significant at the $1 \%$ significance level. This result indicates that all variables in the models are significant as a whole. $R^{2}$ value obtained with the Driscoll-Kraay estimator of Model-1, which considers one-month lagged stock price as a dependent variable, was $38 \%$. In other words, profitability ratios explain the change in one month lagged stock price at the rate of $38 \%$. In the scope of Model-1, NPM can explain one month lagged stock prices at $1 \%$ significance level ( $p$ value 0,004$)$ and ROE can explain it at $10 \%$ significance level. Fs variable, used as a control variable and the constant are also significant at $1 \%$ significance level. Other variables are not statistically significant in explaining changes in stock prices. As a result of analyzes in Model-2 (two months lagged), the model's explanatory power rate is $32 \%$. The only statistically significant variable (except for constant and fs) is NPM at significance level $1 \%$ ( $p$-value 0,003 ). Similar results were also obtained in the Model-3 (three months lagged). Model-3's explanatory power in explaining changes of three months lagged stock prices is $28 \%$ and again, the only statistically significant variable (except for constant and fs) is NPM ( $p$ value 0,003 ). In all three models (Model-1, Model-2, Model-3), it was determined that there is a positive relationship between NPM and stock prices. $1 \%$ increase in NPM leads to increase in stock prices in the Model-1, Model-2 and Model-3 at the rate of $1,4 \%, 1,86 \%$ and $1,32 \%$, respectively. However, in the Model $-1,1 \%$ increase in ROE leads to $0,15 \%$ decrease in stock prices. When all results were taken into consideration, $\mathrm{H}_{0}$ hypothesis was rejected and $\mathrm{H}_{1}$ hypothesis was accepted. In general, among the variables within the scope of the research model, only NPM can explain the changes in stock prices. This result complies with the studies of Karaca and Başşı (2011), Aktaş (2008), Moderes, Abedi and Mirshams (2008), Dehuan and Jin (2008).

As a result of the analysis, linear relationship was confirmed between NPM and stock prices in all three models. Akyatan (2016), Kaya and Öztürk (2015), Aktaş and Ünal (2015) and also Parlakkaya and Kahraman (2017) reached the similar results. On the other hand, Sevim (2016) revealed that there is no significant relationship between ROA, ROE ratios and stock returns. In addition, Aktaş and Ünal (2015) did their research by using quarterly data. In this study, 1, 2 and 3 months lagged stock prices after each quarter period was taken into consideration. It can be said that investors create demand for stocks by looking at NPM. In other words, NPM is the profitability ratio which can lead the investors' decisions. However, due to the fact that explanatory power of models decreases as lags increase, it can be stated that investors' stock investment decisions related to NPM are closely associated with the time. In addition to this, it was surprisingly determined that ROE which represents the profit distributed to the capital owners, is not effective in Model- 2 and Model-3. In the Model1 , it was revealed that there is a negative relationship between ROE and stock prices. When it is thought that supply-demand is effective in changing the share prices, this negative relationship between ROE and the stock prices may be the topic of the next research which is about whether this relationship can be explained by dividend payments.

\footnotetext{
${ }^{8}$ The similar results were also obtained in Model-2 and Model-3.
} 


\section{CONCLUSION}

One of the most important indicators for the stock investors is the price changes of stocks in time. Stock prices change according to supply and demand levels in the market. Generally, several factors including micro and macro factors direct stock prices. In this study that was done in order to find out whether there is a relationship between the company profitability ratios, which is one of the micro factors that show the success of the firms' operations, and the stock price of these firms; the answer was tried to find as to whether the profitability ratios of the companies can be guided when stock investors make their investment decisions.

In the analysis section of the research, more than one profitability ratio were given and the variables used for the study are; net profit margin, gross profit margin, operating profit margin, asset profitability and equity profitability ratios. Data sets related to stock price and profitability ratios were obtained from the Finnet Analysis Expert financial analysis program. The values for the stock price are based on the values that first, second and third months after the quarterly stock price values. The hypothesis to be proposed / tested in order to determine the relationship between profitability ratios and share price was tested by panel regression model. In order to apply the panel regression model, the necessary conditions must be met. The stationarity of the variables was tested by second-generation panel unit root tests, taking into account the cross-sectional dependency as the cross-sectional dependence of profitability and price data of the firms included in the analysis is observed. Moreover, it was determined that all variables except for ROE were not stationary and they had unit roots at level. Then, non-stationary variables were stabilized by taking first and/or second order differences. Within the tests tested to determine the estimation method to be used in the panel regression model, the final result was obtained with the Driscoll-Kraay estimator.

Consequently, it was revealed that all three models were significant and profitability ratios' explanation rate in explaining changes in stock prices was between $28 \%$ and $38 \%$. In all three models, positive relationship between net profit margin and stock price was confirmed. While $1 \%$ increase in NPM led to an increase in stock prices between by $1,32 \%-1,86 \% ; 1 \%$ increase in ROE caused $0,15 \%$ decrease on onemonth lagged stock prices. The effect on this situation can be explained by the investor's position in the market. It can be said that investors realize the increase in ROE, consisted during the period $t$ and therefore they do not demand the stock again in the one-month lagged period $(t+1)$. As a result, absence of demand may have caused a decrease in stock price. In this context, the $H_{0}$ hypothesis, which assumes that there is no relationship between profitability ratios and stock price, was rejected and the $\mathrm{H}_{1}$ hypothesis assuming that there is a relationship between profitability ratios and stock price was accepted. Furthermore, when the results were considered totally, it was seen that only NPM variable explains the changes in stock prices.

There are several factors that should be taken into consideration by investors when making investment decisions. In this study, the relationship between profitability ratios and stock prices was examined and it was attempted to reach the point that whether profitability ratios can be a guide for investing in stocks. However, that considering only one factor while investing can not bring the successful results to achieve desired goals. Because of this reason, investment in stocks may be supported by a diversification of the data set, taking into account other micro and macroeconomic factors. In addition to this suggestion, this study which was done by analyzing the data of companies from many different sectors in BiST-100, can be applied on sector basis or cross-sector comparisons can be made.

\section{REFERENCES}

Aktaş, M. (2008). İstanbul Menkul Kıymetler Borsasında Hisse Senedi Getirileri İle İlişkili Olan Finansal Oranların Araştırılması, İstanbul Üniversitesi İşletme Fakültesi Dergisi, Volume:37, Issue:2, 137-150.

Aktaş, R., \& Ünal , S. (2015). The Relationship Between Financial Efficiency Ratios and Stock Prices: An Empirical Investigation On Insurance Companies Listed In Borsa Istanbul. Journal of Financial Researches and Studies, 7(12), 1-16.

Akyatan , A. (2016). Bist 100 Endeksine Kote Olan Hisse Senetlerinin Getiri Başarılarının Tahmini Üzerine Bir Çalışma. İstanbul Üniversitesi işletme Fakültesi Dergisi, 45(2), 120-130.

Arkan, T. (2016). Thelmportance of Financial Ratios in PredictingStockPriceTrends: A Case Study in EmergingMarkets. Finanse, RynkiFinansowe, Ubezpieczenia, 1(79), 13-26. http://doi.org/10.18276/frfu.2016.79-01

Ayaydın, Hasan-Dağlı, Hüseyin. (2012), “Gelişen Piyasalarda Hisse Senedi Getirisini Etkileyen Makroekonomik Değişkenler Üzerine Bir Inceleme: Panel Veri Analizi”, Atatürk Üniversitesi iiBF Dergisi, Volume.26, Issue.3-4, pp.45-65.

Aydemir, O. Ögel, S. \& Demirtaş, G. (2012). Hisse Senetleri Fiyatlarının Belirlenmesinde Finansal Oranların Rolü, Yönetim ve Ekonomi: Celal Bayar Üniversitesi İktisadi ve İdari Bilimler Fakültesi Dergisi, 19(2), 277-288.

Baltagi, B. H., \& Wu, P. X. (1999). Unequally Spaced Panel Data Regressions with AR(1) Disturbances. Econometric Theory, 15, 814-823.

Bhargava, A., Franzini, L., \& Narendranathan, W. (1982). Serial Correlation and The Fixed Effects Model. Review of Economic Studies, 49, 533-549.

Borsa İstanbul, (2016). Faaliyet Raporu, http://www.borsaistanbul.com/docs/default-source/kurumsal-yonetim/borsa-istanbul-2016faaliyet-raporu.pdf?sfvrsn=6

Breusch, T. S., \& Pagan, A. R. (1980). The Lagrange Multiplier Test and Its Applications to Model Specification Tests in Econometrics. Review of Economic Studies, 47, 239-253.

Cengiz, H., \& Püskül, A. Ö. (2016). Hisse Senedi Getirileri ve Karlıık Arasındaki ilişski: Borsa İstanbul Endeksinde Işlem Gören Işletmelerin Analizi. Yalova Sosyal Bilimler Dergisi, 7(12), 295-306. 
Chu, S. F.,\&Lim, G. H. (1998). Shareperformanceandprofitefficiency of banks in an oligopolistic market: evidencefromSingapore. Journal of Multinational Financial Management, 8(2-3), $\quad$ 155-168. http://doi.org/10.1016/S1042-444X(98)00025-5

Çoşkun, M., Kasım, K., \& Muhammed, U. (2016). Seçilmiş Makroekonomik Değişkenlerle Hisse Senedi Fiyatları Arasındaki ilişki: Türkiye Üzerine Ampirik Bir İnceleme. Finans Politik \& Ekonomik Yorumlar, 53(616), 61-74.

Demir , Y. (2001). Hisse Senedi Fiyatını Etkileyen İşletme Düzeyindeki Faktörler ve Mali Sektör Üzerine iMKB'de Bir Uygulama. Süleyman Demirel Üniversitesi iktisadi ve Idari Bilimler Fakültesi Dergisi, 6(2), 109-130.

Driscoll, J. C., \& Kraay, A. C. (1998). Consistent Covariance Matrix Estimation with Spatially Dependent Panel Data. Review of Economics and Statistics, 80(4), 549-560.

Dücan, E., \& Akal, M. (2017). Komşu Ülkelerle Yapılan Dış Ticaretin DYY Girişleri Üzerine Etkisi: Gelişmekte Olan Ülkeler Için Panel Veri Analiz. Uluslararası Ekonomik Araştırmalar Dergisi, 3(1), 63-80.

Eka, N., Purnamasari, P., Purnamasari, I., \& Gautama, B. P. (2016). The Influence of Financial Performance on Stock Price in Indonesian Oil and Gas Companies. 1st Global Conference on Business, Management and Entrepreneurship (C. 15, pp. 157-160).

Ferrer, R. C., \& Tang, A. (2016). An empirical investigation of the impact of financial ratios and business combination on stock price among the service firms in the Philippines. Academy of Accounting and Financial Studies Journal, 20(2), 104-116.

Greene, W. H. (2002). Econometric Analysis. New Jersey: Prentice Hall.

Güngör, B., \& Kaygın, C. Y. (2015). Dinamik Panel Veri Analizi ile Hisse Senedi Fiyatini Etkileyen Faktörlerin Belirlenmesi. Kafkas Üniversitesi Iktisadi ve İdari Bilimler Fakültesi Dergisi, 6(9).

Hamit-Haggar, M. (2012). Greenhouse Gas Emissions, Energy Consumption and Economic Growth: A Panel Cointegration Analysis From Canadian Industrial Sector Perspective. Energy Economics, 34(1), 358-364. http://doi.org/10.1016/j.eneco.2011.06.005

Hausman, J. A. (1978). Specification Tests in Econometrics. Econometrica, 46(6), 1251-1271.

Hepaktan, E. C., \& Çınar, S. (2012). OECD Ülkelerinde Büyüme-Cari İşlemler Dengesi İlişkisi: Panel Veri Analizi. Anadolu Üniversitesi Sosyal Bilimler Dergisi, 12(1), 43-57.

Hurlin, C., \& Mignon, V. (2007). Second Generation Panel Unit Root Tests.

İlgün, M. F. (2016). Mali Sürdürülebilirlik: OECD Ülkelerine Yönelik Panel Veri Analizi. Atatürk Üniversitesi Iktisadi ve Idari Bilimler Dergisi, $30(1), 69-90$

Jin, D., Zhensu, J. (2008). Firm Performance And Stock Returns: An Empirical Study of the Top Performing Stocks Listed on Shanghai Stock Exchange, Academy of Accounting and Financial Studies Journal, Volume 12, Number 1, p.79-85.

Karaca, S. S.,\&Başcı, E. S. (2011). Hisse Senedi Performansını Etkileyen Rasyolar ve iMKB 30 Endeksinde 2001-2009 Dönemi Panel Veri Analizi, Süleyman Demirel Üniversitesi İktisadi ve İdari Bilimler Fakültesi Dergisi, 16(3), 337-347.

Kaya, A.,\& Öztürk, M. (2015). Muhasebe Karları İle Hisse Senedi Fiyatları Arasındaki İlişki : BisT Firmaları Üzerine Bir Uygulama. Muhasebe ve Finansman Dergisi, 67(Temmuz), 37-54.

Kohansal, M. R.,Dadrasmoghaddam, A., Karmozdi, K. M., \&Mohseni, A. (2013). Relationshipbetween Financial RatiosandStockPricesfortheFoodIndustryFirms in Stock Exchange of Iran. World Applied Programming, 3(October), 512-521.

Le, T.-H., Kim, J., \& Lee, M. (2016). InstitutionalQuality, TradeOpenness, and Financial Sector Development in Asia: An EmpiricalInvestigation. EmergingMarkets Finance andTrade, 52(5), 1047-1059. http://doi.org/10.1080/1540496X.2015.1103138

Mert, M.(2016). SPSS STATAYatay Kesit veri Analizi Bilgisayar Uygulamaları, Detay Yayıncılık: Ankara.

Modares, A., Abedi, S., ve Mirshams, M. (2008). Testing Linear Relationships Between Excess Rate of Return and Financial Ratios, Electronic copy available at: $h$ ttp://ssrn.com/abstract $=1264912$

Mokhtar, M.,Shuib, A., \&Mohamad, D. (2014). Identifyingthe Critical Financial RatiosforStocks Evaluation: A FuzzyDelphiApproach. AIP Conference Proceedings(ss. 348-354). http://doi.org/10.1063/1.4903606

Narayan, P.,\&Reddy, Y. V. (2016). Literature on StockReturns : A Content Analysis. AmityJournal of Finance, 1(1), $194-207$.

Parlakkaya, R. \& Kahraman, Ü. M. (2017). Muhasebe Bilgilerinin Hisse Fiyatlarını Açıklama Düzeyi Üzerine Bir Araştırma: Bist100 Uygulaması, Selçuk Üniversitesi İktisadi ve İdari Bilimler Fakültesi Sosyal Ekonomik Araştırmalar Dergisi, Volume: 17, Issue: 33, 46-58.

Pesaran, H. M. (2007). A Simple Panel Unit Root Test in the Presence of Cross Section Dependence. Journal of Applied Econometrics, 22(2), 265-312.

Pesaran, M. H. (2004). General diagnostictestsforcrosssectiondependence in panels.

Pesaran, M. H., Ullah, A., \& Yamagata, T. (2008). A Bias-Adjusted LM Test of Error Cross-Section Independence. Econometrics Journal, 11, 105-127.

Şak, N. (2015). Panel Birim Kök Testleri. S. Güriş, Stata ile Panel Veri Modelleri (s. 203-269). İstanbul: Der Yayınları. 
Sevim, U. (2016). İ̧̧letme Finansal Oranlarının Hisse Senedi Getirileri Üzerine Etkisi: BiST 100 İmalat İşletmeleri Örneği, Eskişehir Osmangazi Üniversitesi IiBF Dergisi, 11(2), 221-235.

Sharif, T., Purohit, H., \& Pillai, R. (2015). Analysis of Factors Affecting Share Prices: The Case of Bahrain Stock Exchange. International Journal of Economics and Finance, 7(3), 207-216.

Tatoğlu, F. Y. (2016). Panel Veri Ekonometrisi Stata Uygulamalı. İstanbul: Beta Yayınları.

Ullah, H., Sagip, S., \& Usman , H. (2016). The Impact of Dividend Policy on Stock Price Volatility: A Case Study of Selected Firms from Textile Industry in Pakistan. International Journal of Academic Research in Economics and Management Sciences, 5(3), 1-11.

Ün, T. (2015). Stata ile Panel Veri Analizi. S. Güriş, Stata ile Panel Veri Modelleri (s. 40-81). istanbul : Der Yayınları.

Wu, T.-P., Liu, S.-B., \& Hsueh, S.-J. (2016). The Causal Relationship between Economic Policy Uncertainty and Stock Market: A Panel Data Analysis. International Economic Journal, 30(1), 109-122. http://doi.org/10.1080/10168737.2015.1136668

http://www.tuik.gov.tr/PreHaberBultenleri.do?id=24812 (25.11.2017) 